\title{
SZERSZÁMGÉP RÉSZEGYSÉG STATIKAI MEREVSÉGÉNEK VÉGESELEMES VIZSGÁLATA
}

\author{
Kiss Dániel \\ egyetemi tanérsegéd, Miskolci Egyetem, Szerszámgépészeti és Mechatronikai Intézet, \\ Szerszámgépek Intézeti Tanszéke \\ 3515 Miskolc, Miskolc-Egyetemváros, e-mail: kiss.daniel@uni-miskolc.hu
}

\begin{abstract}
Absztrakt
Jelen cikkben bemutatom, milyen módon lehet statikai elemzésre használni egy integrált CAD rendszert. Egy valós példán, ami egy marógép asztala, bemutatom hogyan lehet analitikus módon optimalizálást végezni merevségre és tömegre. A sokrétü numerikus módszer közül a végeselemes módszer ilyen irányú használatát mutatom be.
\end{abstract}

Kulcsszavak: szerszámgép, tervezés, végeselem, mechanikai

\begin{abstract}
During this article I present how an integrated CAD system can be used for optimisation. During a real life example, which is the table of a milling machine, I show how can be analitical optimasiton made for reducing mass thus increase rigidity. Among the several types of numerical methods this article focuses on using FEM.
\end{abstract}

Keywords: machine tool, design, FEM, mechanical

\section{Bevezetés}

Megmunkálógépek üzemeltetése és tervezése, illetve részegységeinek tervezése során figyelembe kell venni minden olyan lehetséges tényezőt, amely az adott gépnek a pontossági és üzemi paramétereivel kapcsolatban áll. Ezen tényezők főként hőtani, kinematikai, dinamikai, illetve szilárdságtani jelenségek közül kerülnek ki. Ezen tényezők hatásával a tervezés fázisában számolnia kell a tervező(k)nek, ugyanis ebben a fázisban a leggazdaságosabb az esetleges hibák feltárása. Mivel a tervezési fázisban fizikailag nem áll rendelkezésre a megmunkálógép, így ezen jelenségeknek a hatását kizárólag analitikus, illetve numerikus módszerek segítségével tudjuk ellenőrizni és szimulálni. [1]

Mivel a korábban említett jelenségek matematikai leírása többnyire bonyolult, a megoldása pedig a geometriai peremfeltételek miatt nehézségekbe ütközik, ezen problémák megoldására számok numerikus eljárás került kifejlesztésre. Ezek közül a talán a legismertebb és legjobb közelítést adó a végeselemes számítási módszer. [2]

Jelen cikkben egy szerszámgép részegység, egész pontosan egy marógép asztala, tervezésén keresztül kívánom bemutatni, hogy egy mai modern integrált tervezőrendszer használata hogyan segíti a tervező dolgát.

\section{Koncepcionális modell}

A tervezendő részegység egy marógép asztala. A marógép asztalok különböző kivitelekben és méretekben elérhetőek, azonban nem kereskedelmi tételek mivel szerves részét képezik az adott 
megmunkálógépnek. Annak függvényében, hogy milyen konstrukcióról beszélünk, illetve milyen tömegü munkadarabot munkálunk meg a szerszámgépen, a marógép asztala több irányú mozgást is végezhet.

Jelen esetben a szóban forgó gépegység az „Ultrapontosságú és Freedome típusú szerszámgépek kifejlesztése" c. GINOP-2.2.1-15-2017-00093 projekt keretében kifejlesztésre kerülő nagypontosságú maróberendezés asztala. A projekt keretein belül kaptunk egy koncepcionális modellt az asztalról, melyet az 1. ábra mutat.
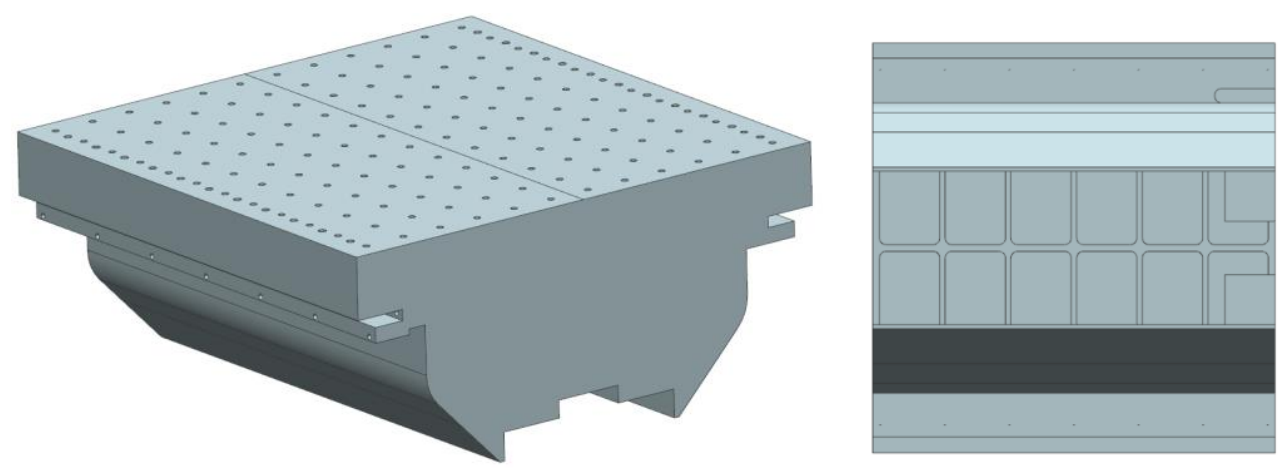

1. ábra. Az elözetes modell és a belső bordázata

Jelen gépnél, mivel nagyméretü és tömegü munkadarabokat kell mozgatni, az asztal csak az X irányú mozgást végzi. A tervezés ezen fázisában még golyós-menetes hajtás volt tervben, de ezt helyszüke miatt későbbiekben hézagmentesített fogaskerekes-fogasléces hajtásra cseréltük. Az asztal egy V alakú ágyban helyezkedik el, ahol azonban nem profilsínes megvezetést alkalmazunk, hanem egy újfajta csúszóvezetéket, mely szintén a projekt keretein belül kerül kidolgozásra.

\section{Végeselemes modell definiálása}

A konkrét tervezési munkát megelőzően megvizsgáltam az előzetes modellt. Ehhez a már korábban említett V-alakú ágy modellt alkalmaztam, illetve egy szimulált alapanyagot, ami egy $3000 \mathrm{~kg}$ tömegü acéltömb. Az asztal és az ágy alapanyagának gömbgrafitos öntöttvasat választottam. Az érintkezési paramétereket acél-acél érintkezést feltételezve definiáltam. A modellen az egyetlen terhelés a gravitáció, ugyanis egy olyan konstrukció elérése a cél, mely statikailag a legmerevebb. A definiált modellt a 2. ábra mutatja. [3]

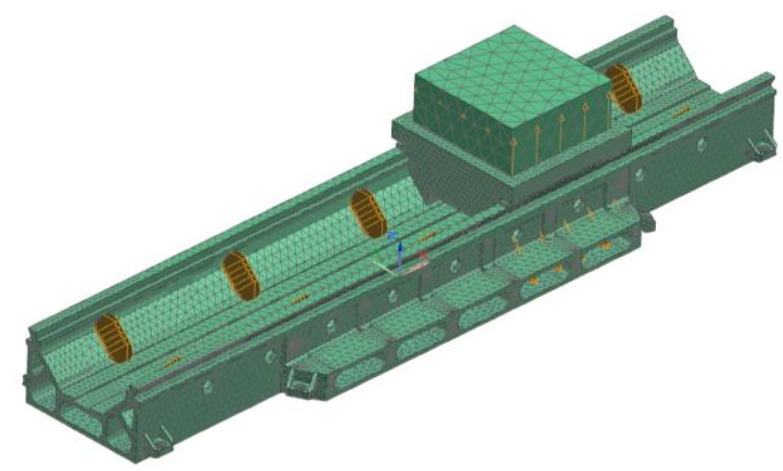

2. ábra. Kényszerezett és végeselem hálózott VEM modell 
Az analízis során azért nem került középre az asztal, mert így két eltérő változatot tudtam egymással összehasonlítani, így az ágy két oldalán szimmetrikusan tudtam ezeket elhelyezni. A szimuláció eredményét a 3. ábra szemlélteti.

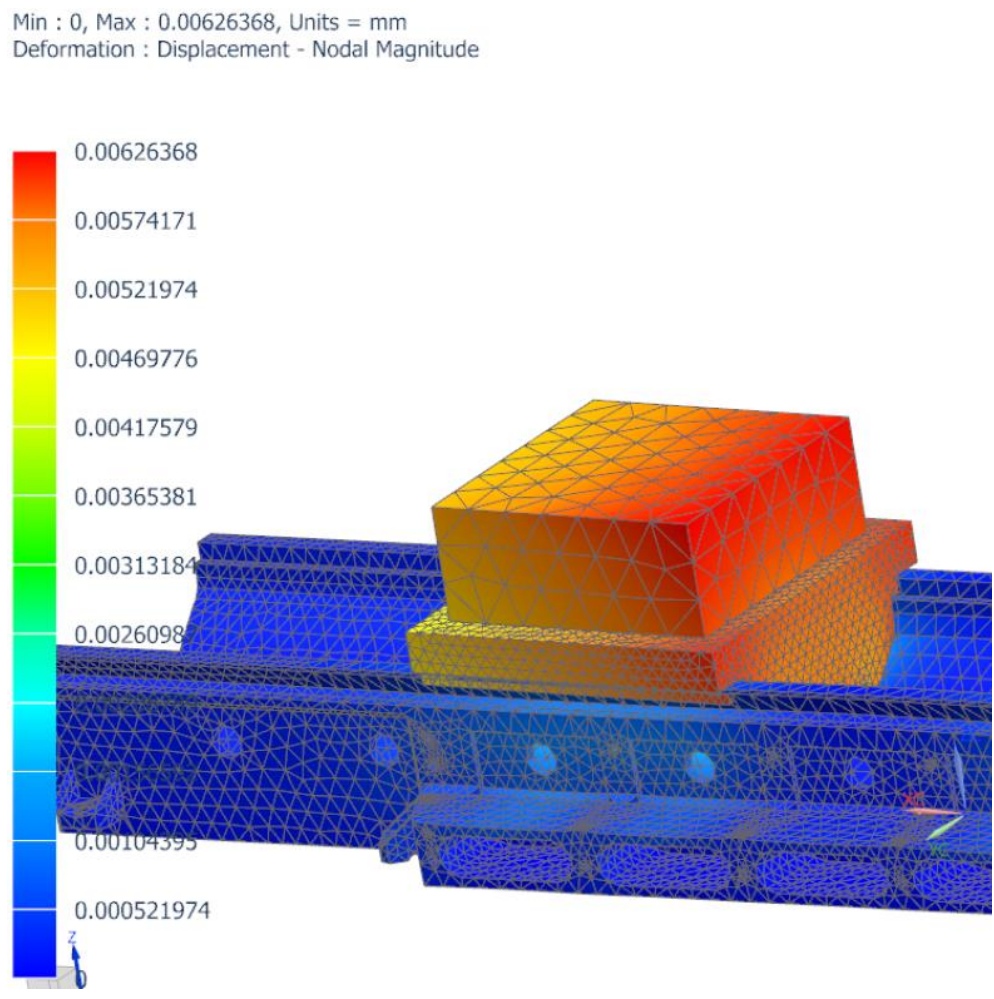

\section{3. ábra. A szimuláció eredménye}

A kapott eredményen jól látható, mivel az asztal nem szimmetrikus, ezen ugyanis szerepelnek még golyósanyák felfogatására kialakított felületek (1. ábra), így a színskála alapján megállapítható, hogy az asztal az Y tengely körül „elbillen”. A kapott elmozdulás ugyan nem tünik számottevőnek, de ettől jobb eredmények is elérhetőek. Továbbá az asztal tömege jelenleg $2679 \mathrm{~kg}$, ami a lehető legkisebbre érdemes csökkenteni úgy, hogy a merevsége nem romlik, továbbá így növelhetők a gép dinamikai jellemzői.

\section{A modell kidolgozása}

Az elözetes tervek alapján több kisebb-nagyobbváltoztatást követően kidolgozásra került az asztal modellje. Az előzetes modell alapján az asztal 1200 x 1200 mm mérettel került definiálásra. Az asztal magasságát későbbiekben meg kellett emelni, mivel főorsók kiválasztásánál történt változtatás után a föorsó kinyúlása csökkent.

Mivel a kereskedelemben föként T-hornyos asztalokat alkalmaznak, így ez az egység is Thornyokkal ellátva készült, azonban ezt később mátrixfuratos megoldásra kellett cserélni. A korábban említett fogasléces hajtás miatt nem kellett változásokat eszközölni, ugyanis a tervezés már ezzel a megoldással került kidolgozásra. 
A merevségre és a tömegre nagy hatással lévő belső kialakítás, ami az asztal belső bordázata, azonban alaposabb átdolgozásra szorult. Ez a részlet az, ahol a legjobban lehet optimalizálásra használni az integrált tervezőrendszerek VEM moduljait. Az asztal belső bordázatának kialakításánál a szerelési és gyártási (öntési) szempontokat kellett fö hangsúllyal figyelembe venni. Az öntés szempontjából az volt a legfontosabb információ, hogy az öntödében, ahol majd az alkatrészek készülnek legalább 30mm-es falvastagsággal kell számolnunk. A 4. ábra mutatja a vizsgált változatokat:
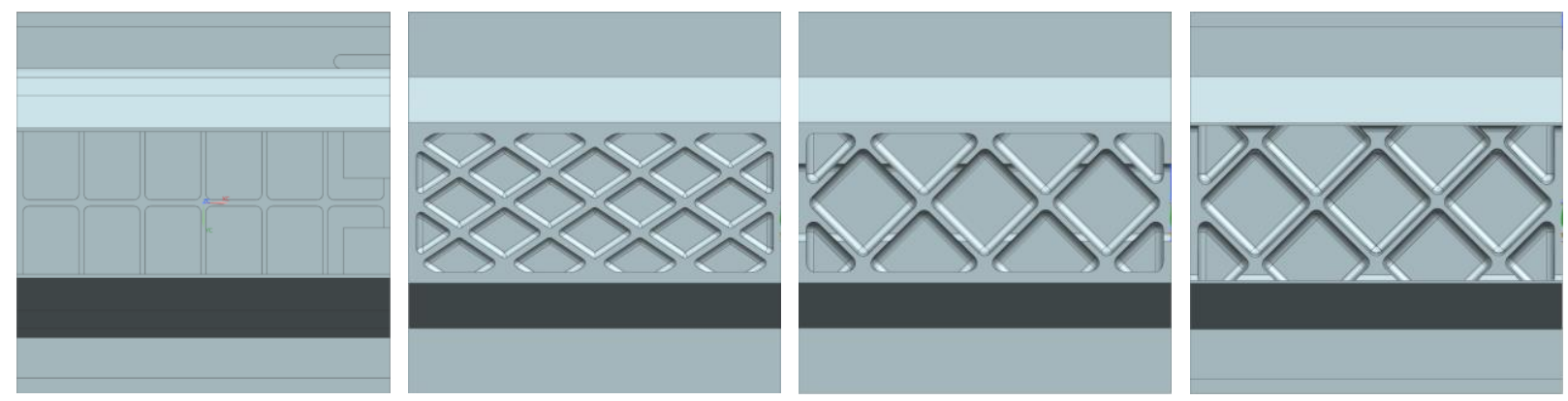

4. ábra. A vizsgált bordázatok (balról jobbra: eredeti verzió, sürü bordás, $45^{\circ}$ fokos ritka bordázat keskeny kivágással, $45^{\circ}$ ritka bordázat széles kivágással)

A vizsgált bordázatok balról jobbra javuló tendenciát mutattak a merevség és a tömeg tekintetében is (5. ábra). A ferde felületek alatt bezáródott üregek képződtek, ezek gyártásához kör alakú nyitások kerültek alkalmazásra az asztallaphoz közel, azonban az öntödéből kapott visszajelzés alapján nagyobb nyitásokra volt szükség, így az ő ajánlásuk került átvezetésre a végleges modellre.

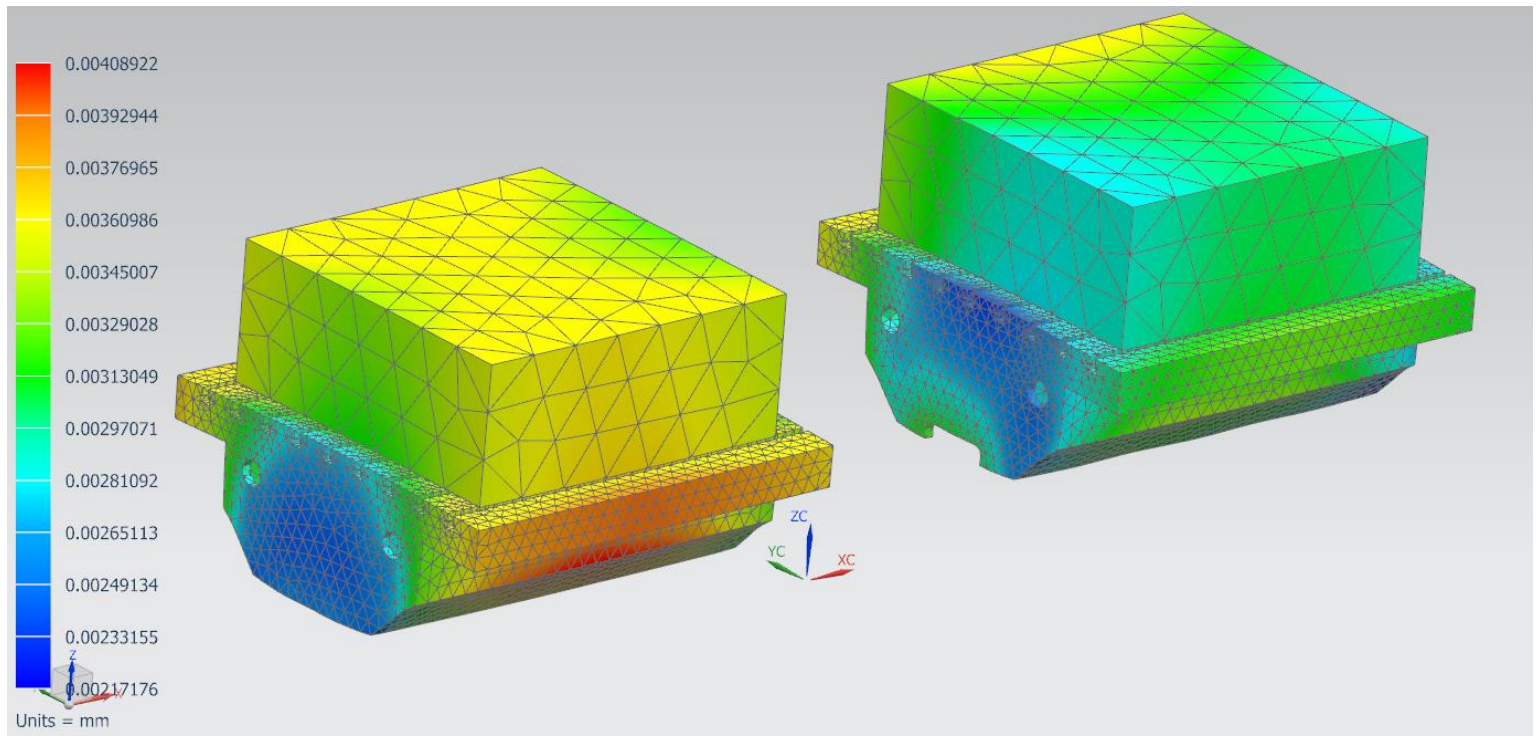

\section{5. ábra. Közbensö változatok összehasonlitása}

Az öntöde által kért módosítás végeselemes módszerrel ellenőrzésre került, mivel, ha az nagy mértékben rontotta volna az asztal tulajdonságait akkor valamilyen kompromisszumos megoldást kellett volna keresni. A 6. ábra mutatja a kiindulási és véglegesített modell közötti maximális $Z$ irányú elmozdulást. 


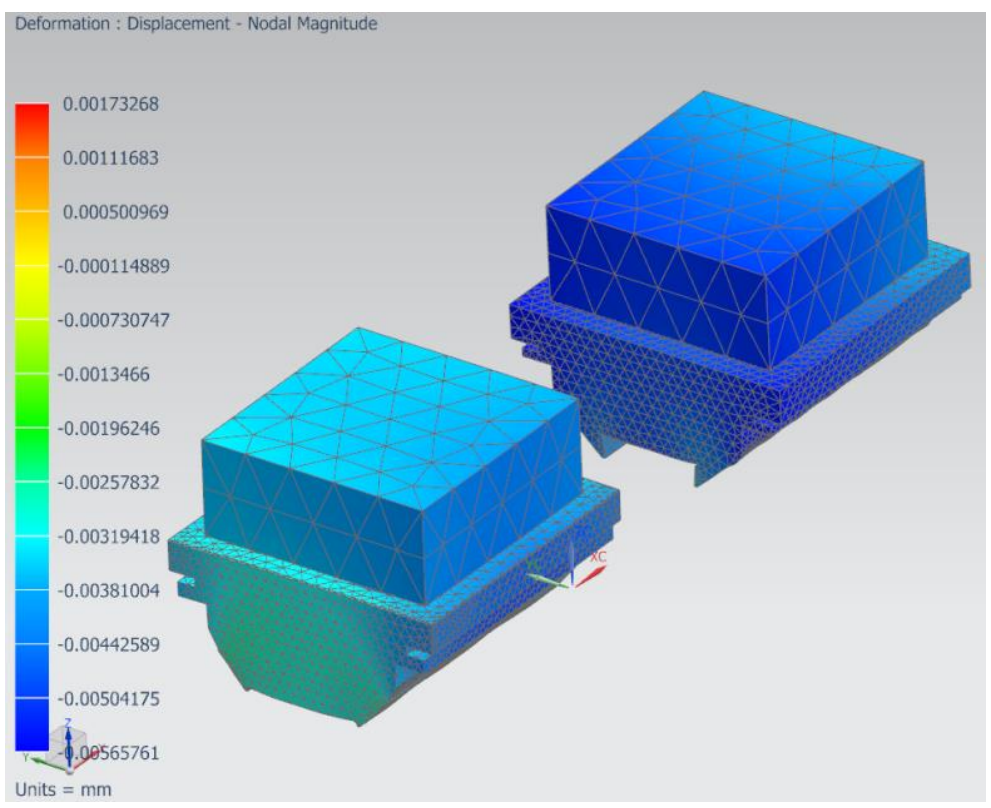

6. ábra. Az eredeti és a véglegesitett modell összehasonlitása

A végleges változatot és a modell alapján öntött és megmunkált kész darabot a 7. ábra mutatja. A bordákból eltávolított viszonylag nagy mennyiségü anyag szinte semmit nem rontott a merevségen, azonban az egyszer használatos habmintás öntési technológia miatt szükséges a nagyméretü áttörések alkalmazása, hogy az öntőmintának megfelelő szilárdságot biztosítson.

A kiindulásként kapott alacsony magasságú koncepcionális modell körülbelül 2700 kg-os tömegét, sikerült $2000 \mathrm{~kg}$ alá csökkenteni úgy, hogy az emelt magasságú asztal merevsége szintén javult, a Z irányú elmozdulást sikerült majdnem a felére csökkenteni.
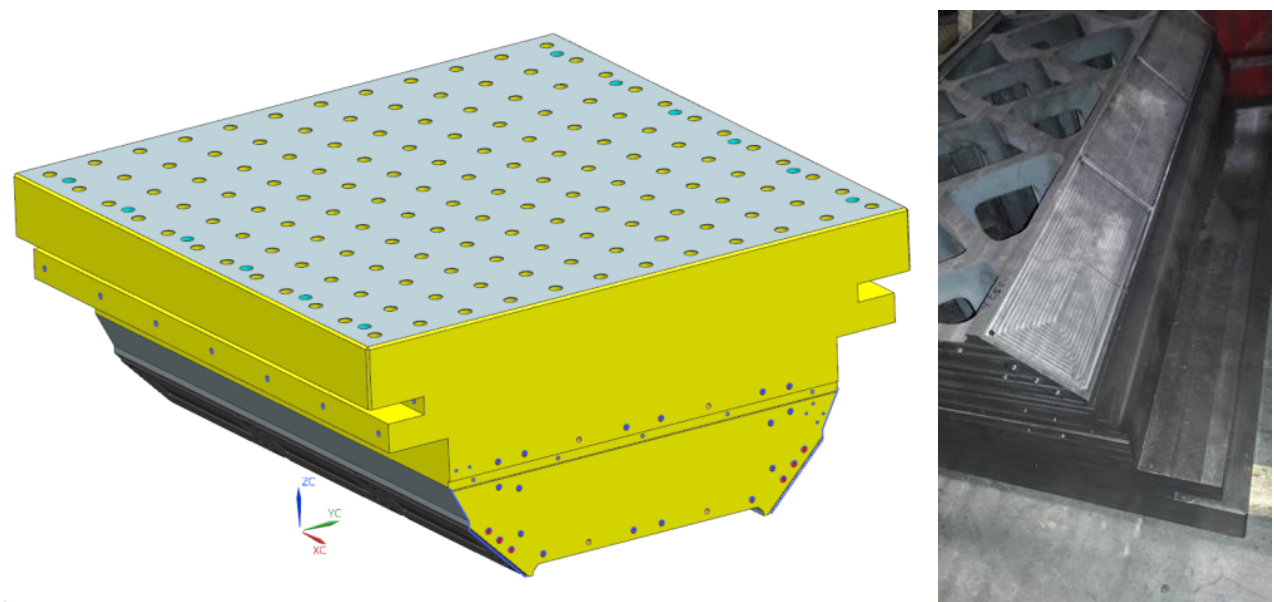

7. ábra. A végleges modell és az öntött és megmunkált öntvény 


\section{5. Összefoglalás}

Cikkemben egy valós példán keresztül bemutattam milyen szempontokra érdemes figyelni egy szerszámgép részegység (adott esetben egy munkaasztal) tervezése során. Jelen esetben a statikai merevség növelése és a tömeg csökkentése együttesen volt a cél. Bemutattam, hogy ilyen esetben egy integrált tervező rendszer hogyan segíti a tervező mérnök munkáját a beépített modulok használatával. A való életből hozott példával szemléltettem a numerikus eljárások hatékonyságát és hogyan alkalmazható adott esetben a tervezés során a különféle tervezési változatok összehasonlító elemzésére. Azt azonban érdemes megemlíteni, hogy a végeselemes modellek definiálása során érdemes bizonyos beállításokra figyelni, amelyekkel a számítási idő, illetve a pontosság optimális értékre hozható.

\section{Köszönetnyilvánítás}

A cikkben ismertetett kutató munka az EFOP-3.6.1-16-2016-00011 jelü „Fiatalodó és Megújuló Egyetem - Innovatív Tudásváros - a Miskolci Egyetem intelligens szakosodást szolgáló intézményi fejlesztése" projekt részeként - a Széchenyi 2020 keretében - az Európai Unió támogatásával, az Európai Szociális Alap társfinanszírozásával valósul meg.

\section{Irodalom}

[1] Baráti, A.: Szerszámgép vizsgálatok, Müszaki Könyvkiadó, Budapest, 1988.

[2] Páczelt, I.: Végeselemmódszer a mérnöki gyakorlatban I. kötet, Miskolci Egyetemi Kiadó pp. 36-37.

[3] Anderl, R., Binde, P.: Simulations with NX. Munich, Carl Hanser Verlag, 2014 https://doi.org/10.3139/9781569904800 